\title{
Juvenile tree growth correlates with photosynthesis and leaf phosphorus content in central Amazonia
}

\author{
Ricardo Antonio Marenco* ${ }^{*}$, Nilvanda dos Santos Magalhães ${ }^{2}$, Paula Romenya dos Santos Gouvêa ${ }^{3}$, \\ Saul Alfredo Antezana-Vera ${ }^{4}$ \\ http://dx.doi.org/10.1590/0034-737X201562020007
}

\begin{abstract}
Light and soil water availability may limit carbon uptake of trees in tropical rainforests. The objective of this work was to determine how photosynthetic traits of juvenile trees respond to variations in rainfall seasonality, leaf nutrient content, and opening of the forest canopy. The correlation between leaf nutrient content and annual growth rate of saplings was also assessed. In a terra firme rainforest of the central Amazon, leaf nutrient content and gas exchange parameters were measured in five sapling tree species in the dry and rainy season of 2008. Sapling growth was measured in 2008 and 2009. Rainfall seasonality led to variations in soil water content, but it did not affect leaf gas exchange parameters. Subtle changes in the canopy opening affected $\mathrm{CO}_{2}$ saturated photosynthesis $\left(A_{\text {pot }} p=\right.$ 0.04). Although $A_{\text {pot }}$ was affected by leaf nutrient content (as follows: $\mathrm{P}>\mathrm{Mg}>\mathrm{Ca}>\mathrm{N}>\mathrm{K}$ ), the relative growth rate of saplings correlated solely with leaf P content $(r=0.52, p=0.003)$. At present, reduction in soil water content during the dry season does not seem to be strong enough to cause any effect on photosynthesis of saplings in central Amazonia. This study shows that leaf $\mathrm{P}$ content is positively correlated with sapling growth in the central Amazon. Therefore, the positive effect of atmospheric $\mathrm{CO}_{2}$ fertilization on long-term tree growth will depend on the ability of trees to absorb additional amount of P.
\end{abstract}

Key words: canopy opening, mineral nutrition, potential nutrient use efficiency, rainfall seasonality.

\section{RESUMO}

\section{O crescimento de arvoretas correlaciona-se com a fotossíntese e teor de fósforo foliar na Amazônia central}

A disponibilidade de luz e o conteúdo de água do solo podem limitar a fixação de carbono de árvores em florestas tropicais. O objetivo deste trabalho foi determinar como as características fotossintéticas de árvores juvenis (arvoretas) respondem às variações na sazonalidade das chuvas, teor de nutrientes da folha e a abertura do dossel da floresta. Avaliou-se também a correlação entre o crescimento anual das arvoretas e o teor de nutrientes na folha. Parâmetros de trocas gasosas e teor foliar de nutrientes foram mensurados, na estação seca e chuvosa de 2008, em cinco espécies de árvores numa floresta de terra-firme na Amazônia central. O crescimento anual das arvoretas foi mensurado em 2008 e 2009. A sazonalidade das chuvas causou variações na umidade do solo, mas não afetou os parâmetros de trocas gasosas. Mudanças sutis na abertura de dossel afetaram a fotossíntese saturada por $\mathrm{CO}_{2}\left(A_{\text {pot }}\right.$, $p=0.04$ ). Embora $A_{\text {pot }}$ tenha sido afetado pelos teores de nutrientes da folha (nesta ordem: $\mathrm{P}>\mathrm{Mg}>\mathrm{Ca}>\mathrm{N}>\mathrm{K}$ ), a taxa de crescimento relativo das arvoretas correlacionou-se apenas com o conteúdo de $\mathrm{P}$ foliar $(r=0.52, p=$

\footnotetext{
Submetido em 11/06/2013 e aprovado em 18/03/2015.

${ }^{1}$ Instituto Nacional de Pesquisas da Amazônia (INPA), Manaus, Amazonas, Brazil. rmarenco@inpa.gov.br

${ }^{2}$ Instituto Nacional de Pesquisas da Amazônia (INPA), Programa de Pós-Graduação em Ciências de Florestas Tropicais, Manaus, Amazonas, Brazil. nilvandamagalhaes@gmail.com

${ }^{3}$ Instituto Nacional de Pesquisas da Amazônia (INPA), Programa de Pós-Graduação em Agricultura do Trópico Úmido, Manaus, Amazonas, Brazil. paulagouvea.bio@gmail.com

${ }_{4}^{4}$ Instituto Nacional de Pesquisas da Amazônia (INPA), Programa de Pós-Graduação em Botânica, Manaus, Amazonas, Brazil. Manaus, Amazonas, Brazil. saulantve @ hotmail.com

*Corresponding author: rmarenco@inpa.gov.br
} 
0.003). Na atualidade, o declínio da umidade do solo durante a estação seca não parece ser forte o suficiente para causar efeito na fotossíntese de arvoretas na Amazônia central. Mostra-se neste estudo que o conteúdo de P foliar está positivamente correlacionado com o crescimento de arvoretas na Amazônia central e, portanto, o efeito positivo da fertilização de $\mathrm{CO}_{2}$ atmosférico sobre o crescimento das árvores em longo prazo dependerá da capacidade destas para absorver quantidades adicionais de $\mathrm{P}$.

Palavras-chave: abertura do dossel, nutrição mineral, potencial de eficiência de utilização de nutrientes, sazonalidade de chuvas.

\section{INTRODUCTION}

Growth rates of plants depend on several factors, including soil water content (Wagner et al., 2012) and availability of mineral nutrients (Wright et al., 2011; Santiago et al., 2012). In addition, light availability in the forest understory may also limit sapling growth (LopesToledo et al., 2008; Mendes \& Marenco, 2010). Because of light limitation for photosynthesis, juvenile trees beneath the forest understory often take as long as 80 years to grow to $10 \mathrm{~cm}$ in diameter (Clark \& Clark 2001) and perhaps it takes longer to reach the forest canopy.

In comparison with the attention given to canopy trees, mineral nutrition of trees at the juvenile stages has been little studied, particularly in the Amazon. The availability of $\mathrm{N}$ and $\mathrm{P}$ often limits carbon assimilation in several ecosystems (Elser et al., 2007). An N/P ratio above 16 in the plant tissue can indicate low soil $\mathrm{P}$ availability (Güsewell, 2004). In young trees growing beneath the forest canopy, most of carbon assimilation occurs during the short periods of high intensity light (sunflecks) that puncture the forest canopy (Pearcy, 1990). Hence, high potential nutrient use efficiency is of paramount importance for plant growing in poor soils, otherwise fitness and survival are in jeopardy (Aerts \& Chapin, 2000). In addition to light and nutrient availability, soil water content is another factor that influences photosynthesis and plant growth, and over a wide range of plant species and growth conditions, there seems to be a positive correlation between plant growth and photosynthetic rates (Kruger \& Volin, 2006). Currently, the mild dry period in central Amazonia is limited to only a few months; however, the magnitude of the effect of reduction in soil water content on tree growth during the dry season remains to be elucidated (Marenco et al., 2014a). Amazonian soils are highly weathered, and consequently very low in phosphorus. In central Amazonia for example, Magalhães et al. (2014) reported about $1 \mathrm{mg} \mathrm{kg}^{-1}$ of Mehlich-extractable P. Although the soil is poor in nutrients, biodiversity of central Amazonica is high. In one hectare more than 600 trees (diameter at breast height above $10 \mathrm{~cm}$ ) from 280 species can be found (Oliveira \& Scott, 1999). Based on soil characteristics of the central Amazon, in this study is hypothesized that in this region, variations in leaf $\mathrm{P}$ content affect photosynthetic traits, and that increases in photosynthesis ultimately result in faster growth rates of saplings. The hypothesis that variations in canopy opening across microsites and changes in soil water content over the year affect leaf traits was also assessed in this study. Thus, the objective of this work was to determine how photosynthetic traits of juvenile trees respond to variations in soil water content, leaf nutrient content, and forest canopy opening in central Amazonia. The correlation between leaf nutrient content and annual growth rate of saplings was also assessed.

\section{MATERIALS AND METHODS}

\section{Study area and plant material}

The study was conducted $60 \mathrm{~km}$ north of Manaus (02³6'21" S; 6008'11" W), state of Amazonas, Brazil, in a terra firme rainforest (ZF2 reserve). The predominant soil type is an Oxisol (yellow latosol in the Brazilian classification), clay texture and low $\mathrm{pH}$. The region has characteristics of a humid equatorial climate, with a short mild dry season (July-September, with a rainfall of 50$100 \mathrm{~mm}$ per month), and a dry-rainy transition month (October). The rainy season lasts from November to May (200-300 mm month ${ }^{-1}$ ); mean annual rainfall is $2420 \mathrm{~mm}$ and average annual temperature is about $26^{\circ} \mathrm{C}$ (Malhi \& Wright, 2004). Atmospheric $\mathrm{CO}_{2}$ concentration in the forest understory is about $450 \mathrm{ppm}$ (Marenco et al. 2014b). In this study, saplings ( 0.8 to $2.4-\mathrm{m}$ tall) of five tree species were used: Minquartia guianensis Aubl., Guatteria olivacea R.E.Fr, Rinorea guianensis Aubl., Simarouba amara Aubl., and Duroia macrophylla Huber (Table 1). As the study was conducted under natural field conditions, the number of species was limited by natural damages underwent by selected saplings (e.g., mechanical injuries of shoots, herbivory or attack of pathogens). Thus, only species with at least three saplings (replications) per species (growing under the forest understory) were included in the study. 


\section{Gas exchange and specific leaf area}

Gas exchange parameters were measured using an infrared gas analyzer (Li-6400, Li-Cor, NE, USA) in three saplings per species and two leaves per plant, in the rainy and dry season of 2008. Data were collected at a temperature of $28 \pm 1^{\circ} \mathrm{C}$ and relative humidity of $70 \pm$ $5 \%$. Light saturated photosynthesis $\left(A_{\max }\right)$ and stomatal conductance $\left(g_{\mathrm{s}}\right)$ were measured at $1000 \mu \mathrm{mol} \mathrm{m} \mathrm{m}^{-2} \mathrm{~s}^{-1}$ and $\mathrm{CO}_{2}$ concentration of $380 \mathrm{ppm}$. $A_{\max }$ and $g_{\mathrm{s}}$ data were collected between 06:00 and 18:00 at about 30-minute intervals. Photosynthetic rates at a $\left[\mathrm{CO}_{2}\right]$ of $2000 \mathrm{ppm}$ and light saturation (hereinafter termed to as $A_{\text {pot }}$ ) were also measured. $A_{\text {pot }}$ on a mass basis was obtained by multiplying $A_{\text {pot }}$ (per unit leaf area) by SLA ( $A_{\text {pot-mass }}=$ $A_{\text {pot-area }} \times$ SLA). Specific leaf area (SLA, the leaf area to leaf mass ratio), fresh leaf thickness $\left(L_{\mathrm{T}}\right)$ and leaf nutrient contents were also determined. The SLA was measured in a sample of six disks of $240 \mathrm{~mm}^{2}$ per leaf and seven leaves per plant. Leaf dry mass was obtained after oven drying at $72{ }^{\circ} \mathrm{C}$ until constant mass. $L_{\mathrm{T}}$ was measured in the field with digital calipers (accuracy of $10 \mu \mathrm{m}$ ) in 240 $\mathrm{mm}^{2}$ leaf disks (two per leaf). Leaves similar in appearance to those used in photosynthetic determinations were used to determine SLA and $L_{\mathrm{T}}$. When the amount of leaf tissue (of the two leaves used for $A_{\max }$ measurements) was not enough to perform chemical analysis, the leaf sample was complemented with other leaves from the same plant and similar in appearance to those used in photosynthetic determinations.

\section{Leaf nutrient content}

Nitrogen was determined using the Kjeldahl method. $\mathrm{K}, \mathrm{Ca}$ and $\mathrm{Mg}$ by atomic absorption spectrophotometry (PerkinElmer 1100B; PerkinElmer Inc., Waltman, MA, USA). Leaf $\mathrm{P}$ was measured using ammenium molybdate and the absorbance read at 660nm (Shimadzu UVmini 1240, Shimadzu Corp., Kyoto, Japan). Potential use efficiency for nitrogen (PNUE), phosphorus (PPUE), potassium (PKUE), calcium (PCaUE) and magnesium (PMgUE) were determined as the $A_{\text {pot-mass }}$ to leaf nutrient content ratio. Leaf nutrient contents were determined in the dry and rainy season of 2008.

\section{Sapling growth}

Diameter $(D)$ and height $(H$, from the base of the plant to the apex) of saplings were measured in January and December of 2008 and 2009. Stem diameter was measured (mean of two measurements taken at right angles from each other) with digital calipers at $50 \mathrm{~cm}$ from the soil surface. At the end of the study period, average annual increase in height (AIH) and diameter (AID) and annual increase in biomass per plant $(\Delta \mathrm{B})$ were determined. In addition, the annual relative growth rate (RGR, the annual biomass gain to initial biomass ratio) was calculated as $\left(\mathrm{B}_{\mathrm{tf}}-\mathrm{B}_{\mathrm{ti}}\right) / \mathrm{B}_{\mathrm{ti}}$, where $\mathrm{B}_{\mathrm{tf}}$ and $\mathrm{B}_{\mathrm{ti}}$ stand for the biomass of saplings at the end $\left(t_{f}\right)$ and the beginning of a 12-month period $\left(\mathrm{t}_{\mathrm{i}}\right)$. Biomass of saplings $(\mathrm{B}$, in gram) was estimated as follows (Hughes et al., 1999): $\mathrm{B}=(\exp (1.0583 \times$ $\left.\left.\ln \left(D^{2}\right)+4.9375\right)\right) \times 1.143$; where $D$ is in centimeter.

\section{The physical environment and statistical analyses}

Photosynthetic photon flux $(Q)$, air temperature, air relative humidity $(\mathrm{RH})$ and precipitation were recorded above the forest canopy (in 2008 and 2009) at the nearest open place, the top of a $40 \mathrm{~m}$ tall observation tower, 3.3 $\mathrm{km}$ away from the study site. Above canopy, $Q$ data were logged at the observation tower $\left(Q_{\text {open }}\right)$ at 15-minute intervals with a quantum sensor (Li-190SA, Li-Cor, NE, USA) connected to a datalogger (Li-1400, Li-Cor, NE, USA). Air temperature and RH were registered (Humitter 50y, Vaisala Oy, Finland) at 30 minute intervals at the same place. At some points on the forest floor, close-by to the selected plants, daytime air temperature, understory photosynthetic photon flux $\left(Q_{\text {und }}\right)$, and RH were also measured in August (dry season) and December wet season) of 2008. In both seasons (2008) and at each plant location, the fraction of sky visible (FSV, the ratio of canopy openings to the whole projected area of the forest canopy) was determined using a canopy analyzer (LAI-2000 Plant Canopy Analyzer, Li-Cor, NE, USA) using two synchronized sensors, as previously described (Mendes \& Marenco, 2010). In the dry and rainy season (2008), soil water content (water volume / soil sample volume) was determined in 40 undisturbed $100-\mathrm{cm}^{3}$ soil samples collected nearby the selected plants, at a depth of 100-200 mm. Soil water content was determined after

Table 1. Family, plant height $(H)$ and plant stem diameter $(D$, at $50 \mathrm{~cm}$ from soil surface) of the species used in the study. $D$ and $H$ refer to values at the beginning of the experiment

\begin{tabular}{lccc}
\hline Species & Family & $\boldsymbol{H}(\mathbf{m})$ & $\boldsymbol{D}(\mathbf{m m})$ \\
\hline M.guianensis & Olacaceae & $0.92-1.57$ & $4.33-9.49$ \\
G.olivacea & Annonaceae & $1.04-1.51$ & $6.61-8.33$ \\
R.guianensis & Violaceae & $0.92-1.45$ & $5.35-13.0$ \\
S.amara & Simaroubaceae & $0.87-1.00$ & $6.69-8.42$ \\
D.macrophylla & Rubiaceae & $0.79-2.37$ & $5.15-14.0$ \\
\hline
\end{tabular}


oven-drying the soil sample at $105^{\circ} \mathrm{C}$ until constant mass. A second set of soil samples $(n=4)$ similarly collected was used for chemical and physical analyses, as previously described (Magalhães et al., 2014).

All data were submitted to analysis of variance (ANOVA) to assess the effect of rainfall seasonality on the studied parameters. Because the same set of plants was measured in both seasons, data were analyzed using two-way repeated measures ANOVA. Regression analysis was carried out to determine the effect of mineral nutrition on leaf photosynthesis. For variables without a direct cause-effect relationship (FSV versus RGR or photosynthesis) the Pearson correlation coefficient $(r)$ was calculated. Tukey post-hoc test was used for comparison of means $(p<0.05)$. The SAEG 9.0 package of the Federal University of Viçosa-Brazil was used for statistical analyses.

\section{RESULTS}

\section{The physical environment}

Average annual rainfall during the study period was $2802 \mathrm{~mm}$ (Figure 1A), 16\% higher than the historical mean for the region. Above the canopy, average monthly air temperatures ranged from $24.0^{\circ} \mathrm{C}$ to $26.9{ }^{\circ} \mathrm{C}$ (mean of $25.4{ }^{\circ} \mathrm{C}$ ). Average monthly $Q_{\text {open }}$ values varied from 22.8 to $34.0 \mathrm{~mol} \mathrm{~m}^{-2}$ day $^{-1}$ (Figure $1 \mathrm{~A}$ ), with a maximum mean of $980 \mu \mathrm{mol} \mathrm{m} \mathrm{m}^{-2} \mathrm{~s}^{-1}$ at noon (data not shown). Maximum understory irradiance $\left(Q_{\text {und }}\right)$ was about 20 $\mu \mathrm{mol} \mathrm{m} \mathrm{s}^{-2} \mathrm{~s}^{-1}$ (Figure 1B). During daytime, air temperature on the forest floor ranged from 21.9 to $27.0{ }^{\circ} \mathrm{C}$, whereas relative humidity was above $90 \%$.

Soil water content was significantly lower $(p<0.05)$ in the dry season (mean of $47.3 \%, \mathrm{v} / \mathrm{v}$ ) than in the rainy season (mean of $51.3 \%$, v/v). Soil $\mathrm{pH}_{\mathrm{H} 20}$ was 3.97 and soil Mehlich-extractable $\mathrm{P}$ content was $1.68 \mathrm{mg} \mathrm{kg}^{-1}$. Soil concentrations of $\mathrm{K}, \mathrm{Ca}$ and $\mathrm{Mg}$ were 46.7, 37.0, and $14.5 \mathrm{mg} \mathrm{kg}^{-1}$, respectively. Sand, silt and clay content were 112,150 and $738 \mathrm{~g} \mathrm{~kg}^{-1}$, respectively. Soil analysis confirmed that the soil in study area had high clay content and that the soil P content was very low. Values of FSV did not differ between seasons (mean of $0.03, p>0.05$ ) and were similar among individual species within the study area (Table 2) indicating that, on average, saplings over the study area received similar amount of light, which allows one to make reliable comparison among species.

\section{Leaf nutrient content}

Content of leaf mineral nutrients varied among species. It was found that the range of nutrient content was wider for $\mathrm{Ca}$ and $\mathrm{K}$ than for $\mathrm{N}$ or $\mathrm{P}$ (Table 2). On average, the N/P ratio was 40.3 , almost 10 times higher than the $\mathrm{N} / \mathrm{K}$ ratio. Calcium and $\mathrm{K}$ were found in similar amounts in the leaf tissue, but $\mathrm{K}$ content was the double of that of $\mathrm{Mg}$, and 15 times as much the content of leaf $\mathrm{P}$ (Table 2).

\section{Photosynthetic traits and nutrient use efficiency}

The majority of stomata were open between 09:00 and 14:00 (Figure 2). Thus, only data collected between 09:00 and 14:00 were used for comparison among species or between seasons. Photosynthetic parameters $\left(A_{\max }, A_{\mathrm{pot}}, g_{\mathrm{s}}\right)$ were not affected by rainfall seasonality $(p>0.05)$, thus data sets over seasons were analyzed together. Photosynthetic rates differed among species, and on average $A_{\text {pot }}$ per unit leaf area $\left(A_{\text {pot-area }}\right)$ more than doubled the values observed for $A_{\max }$ (Table 2). On the other hand, $g_{\mathrm{s}}$ did not vary across species; it was found a mean value of $0.11 \mathrm{~mol} \mathrm{~m}^{-2} \mathrm{~s}^{-1}$. $A_{\text {pot-area }}$ was responsive to variation in leaf nutrient content $(p \leq 0.05$, Figure 3$)$. The highest determination coefficient was observed between $A_{\text {pot }}$ and leaf P content $\left(r^{2}=0.45, p \leq 0.01\right)$, which was almost the double the $r^{2}$ value observed for the $A_{\text {pot-area }}$-leaf N relationship (Figure 3A, B). Regarding the response of $A_{\text {pot-area }}$ to variation in leaf nutrient contents, the $r^{2}$ values followed this order of importance: $\mathrm{P}>\mathrm{Mg}>\mathrm{Ca}>\mathrm{N}>\mathrm{K}$ (Figure $3 \mathrm{~A}-\mathrm{C}$ ).
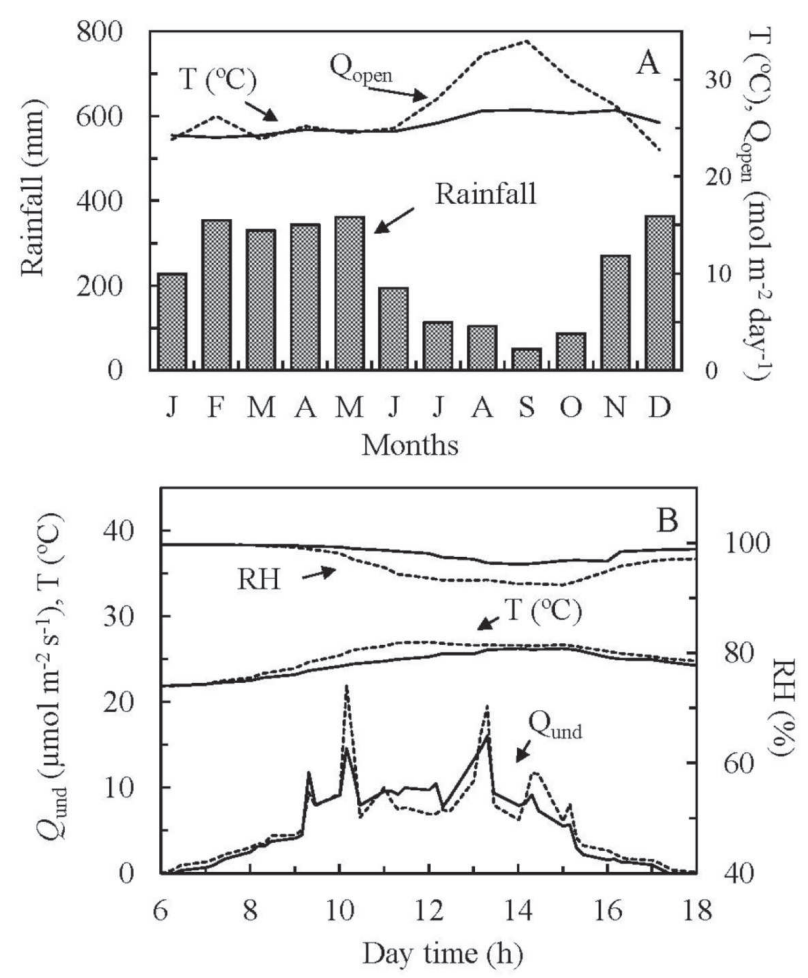

Figure 1. Monthly precipitation (mm, dark bar), mean air temperature ( $\mathrm{T}$, solid line) and above canopy photosynthetic photon flux $\left(Q_{\text {open }}\right.$, dashed line) in the study area (A) and understory photosynthetic photon flux $\left(Q_{\text {und }}\right)$, temperature $(\mathrm{T})$ and relative humidity (RH) on the forest floor in August (dry season, dashed line) and December (rainy season, solid line) of 2008 (B). For panel A data were collected in 2008 and 2009. 
Values of PCaUE, PMgUE and PKUE, but not PNUE or PPUE, varied among species $(p \leq 0.05$, Table 3$)$. The mean PPUE value $\left(361 \mu \mathrm{mol} \mathrm{g} \mathrm{g}^{-1} \mathrm{~s}^{-1}\right)$ was about 40 times as high as that of the PNUE value, and about six to twelve times as much as the photosynthetic use efficiency of $\mathrm{K}, \mathrm{Ca}$ and $\mathrm{Mg}$ (Table 3). PNUE decreased as the leaf $\mathrm{N}$ content increased $\left(r^{2}=0.23, p<0.01\right.$, Figure $3 \mathrm{D}$, inset), indicating that as leaf $\mathrm{N}$ content increased more $\mathrm{N}$ was allocated to non-photosynthetic compounds. Nevertheless, the increases in leaf $\mathrm{N}$ content more than offset the decline in its use efficiency and, as a result $A_{\text {pot-mass }}$ increased with PNUE (Figure 3D). Values of PPUE rapidly declined as leaf $\mathrm{P}$ content increased (Figure $3 \mathrm{E}$, inset). Therefore, $A_{\text {pot-mass }}$ did not respond to changes in PPUE (Figure 3E). The lack of correlation between PPUE, PCaUE, PMgUE, PKUE and $A_{\text {pot-mass }}$ (Figure $3 \mathrm{E}, \mathrm{F}$ ) indicates that as the leaf content of these elements increased, less efficiently they were used.

\section{Leaf traits and sapling growth}

Although there was a decline in soil water content in the dry season, the rainfall seasonality did not affect leaf traits. Therefore, data collected over seasons were combined for data analysis. In comparison with $L_{\mathrm{T}}$, SLA varied only within a narrow range, from 14.3 to $20.5 \mathrm{~m}^{2}$ $\mathrm{kg}^{-1}$ (Table 2), which is within the range observed in other tree species in the same region (Marenco \& Vieira, 2005, Mendes \& Marenco, 2015). There was no difference among species on AIH, AID or $\Delta B$ (Table 2), indicating that differences on growth rates across microsites were related to environmental factors rather than differences on the genetic make-up of the species.

Growth of saplings increased with increases in leaf P content (Figure 4C). Even though all study elements significantly affected photosynthetic parameters, changes in leaf concentrations of $\mathrm{N}, \mathrm{Ca}, \mathrm{K}$ and $\mathrm{Mg}$ did not affect sapling growth ( $p>0.05$, data not shown), suggesting that they followed $\mathrm{P}$ in importance. An increase in either $A_{\text {pot-area }}$ or $A_{\text {pot-mass }}$ led to an increase in sapling growth ( $p<0.05$, Figure 4A, B), perhaps because potential photosynthesis significantly increased in response to FSV (Figure 5A). The correlation between RGR and FSV was not significant ( $p=0.055$, Figure 5B).

\section{DISCUSSION}

\section{The physical environment}

Values of $Q_{\text {und }}$ reported in this study are similar to those found in previous studies in the same area (Marenco \& Vieira, 2005; Magalhães et. al. 2014). Although soil water content declined in the dry season, it was close to

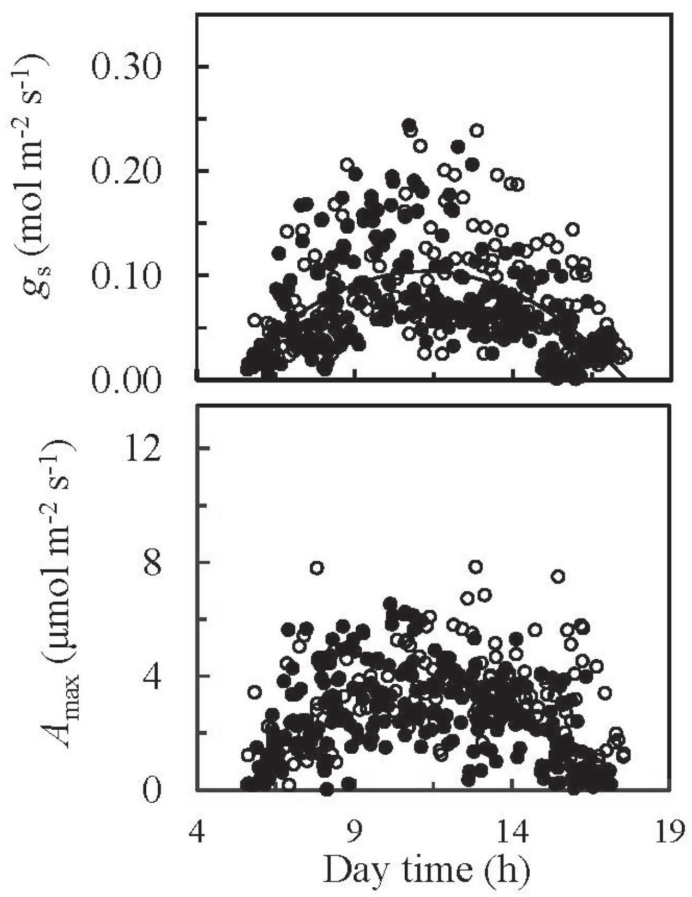

Figure 2. Diurnal variation in stomatal conductance ( $g_{\mathrm{s}}$, upper panel) and light saturated photosynthesis $\left(A_{\max }\right.$, lower panel) in the dry (solid circle) and wet season (open circle) of 2008. Each symbol represents data collected from one leaf.

Table 2. Light-saturated photosynthesis $\left(A_{\max } \mu \operatorname{mol}\left(\mathrm{CO}_{2}\right) \mathrm{m}^{-2} \mathrm{~s}^{-1}\right)$, potential photosynthesis $\left(A_{\text {pot-are }} \mu \mathrm{mol}\left(\mathrm{CO}_{2}\right) \mathrm{m}^{-2} \mathrm{~s}^{-1}\right)$, stomatal conductance $\left(g_{\mathrm{s}}, \mathrm{mol}\left(\mathrm{H}_{2} \mathrm{O}\right) \mathrm{m}^{-2} \mathrm{~s}^{-1}\right)$, annual increase in biomass per plant $\left(\Delta \mathrm{B}\left(\mathrm{g}(\mathrm{MS})\right.\right.$ year $\left.{ }^{-1}\right)$, annual increase in height $(\mathrm{AIH}, \mathrm{m}$ year ${ }^{1}$ ) and diameter (AID, mm year-1), specific leaf area (SLA, $\left.\mathrm{m}^{2} \mathrm{~kg}^{-1}\right)$, fresh leaf thickness $\left(L_{\mathrm{T}}, \mathrm{mm}\right)$ and fraction of sky visible (FSV, unitless) in five Amazonian tree species. Each value (for leaf trait) represents the mean of three plants per species (two leaves per plant for photosynthesis and $g_{\mathrm{s}}$ ) across rainfall seasons of 2008. For sapling growth, each value denotes the mean of three plants per species over the years 2008 and 2009. FSV was measured around each plant, each values stands for the mean across rainfall seasons of 2008

\begin{tabular}{llcccccccc}
\hline Species & $\boldsymbol{A}_{\max }$ & $\boldsymbol{A}_{\text {pot-area }}$ & $\boldsymbol{g}_{\boldsymbol{s}}$ & $\boldsymbol{\Delta} \mathbf{B}$ & $\mathbf{A I H}$ & $\mathbf{A I D}$ & $\mathbf{S L A}$ & $\boldsymbol{L}_{\boldsymbol{T}}$ & FSV \\
\hline M. guianensis & $3.16 \mathrm{~b}$ & $8.50 \mathrm{ab}$ & $0.07 \mathrm{a}$ & $22.35 \mathrm{a}$ & $0.10 \mathrm{a}$ & $0.87 \mathrm{a}$ & $17.64 \mathrm{ab}$ & $0.13 \mathrm{c}$ & $0.02 \mathrm{a}$ \\
G. olivacea & $4.93 \mathrm{ab}$ & $10.17 \mathrm{ab}$ & $0.12 \mathrm{a}$ & $18.36 \mathrm{a}$ & $0.10 \mathrm{a}$ & $0.65 \mathrm{a}$ & $14.41 \mathrm{~b}$ & $0.21 \mathrm{ab}$ & $0.02 \mathrm{a}$ \\
R. guianensis & $4.04 \mathrm{ab}$ & $9.31 \mathrm{ab}$ & $0.11 \mathrm{a}$ & $25.86 \mathrm{a}$ & $0.07 \mathrm{a}$ & $0.94 \mathrm{a}$ & $20.54 \mathrm{a}$ & $0.15 \mathrm{c}$ & $0.02 \mathrm{a}$ \\
S. amara & $5.14 \mathrm{a}$ & $11.71 \mathrm{a}$ & $0.13 \mathrm{a}$ & $29.04 \mathrm{a}$ & $0.05 \mathrm{a}$ & $1.09 \mathrm{a}$ & $14.32 \mathrm{~b}$ & $0.23 \mathrm{a}$ & $0.05 \mathrm{a}$ \\
D. macrophylla & $3.16 \mathrm{~b}$ & $6.94 \mathrm{~b}$ & $0.12 \mathrm{a}$ & $23.69 \mathrm{a}$ & $0.05 \mathrm{a}$ & $0.57 \mathrm{a}$ & $20.13 \mathrm{a}$ & $0.16 \mathrm{bc}$ & $0.03 \mathrm{a}$ \\
\hline Mean & 4.09 & 9.32 & 0.11 & 23.86 & 0.07 & 0.82 & 17.41 & 0.18 & 0.03 \\
\hline
\end{tabular}

Means within columns followed by same letters do not differ according to Tukey's test at 5\% probability. 


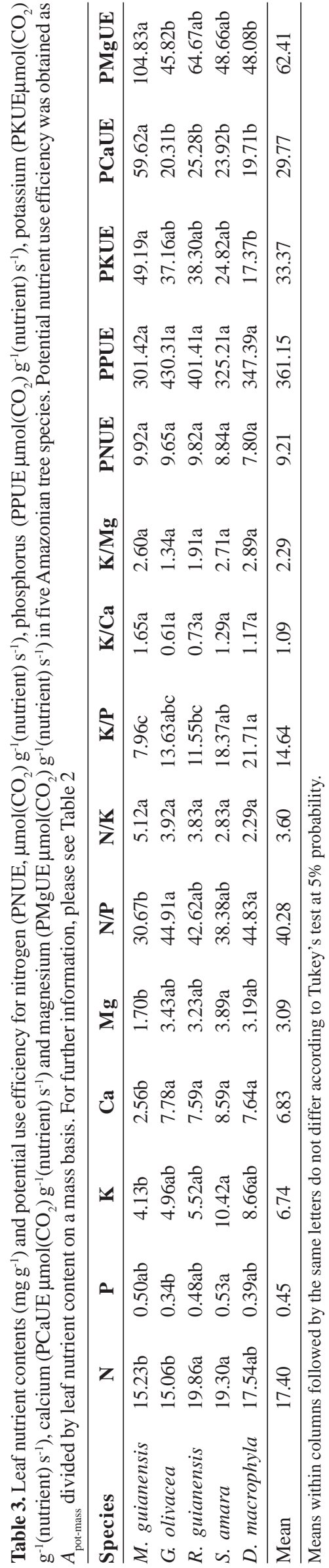

the soil water content at field capacity (Ferreira et al., 2002). This explains the lack of an effect of soil water content on leaf traits. In this study, the decline in soil water content in the dry season was not enough to cause significant reduction on the studied parameters, which is in agreement with previous results reported by Mendes \& Marenco (2010) and Mendes et al. (2013). It is worth noting, however, that the annual rainfall in the study period was a little higher than the historical mean for the region. Obviously, a different plant performance can be found if the dry season extends more than expected for a typical year.

\section{Plant growth}

Low annual increase in diameter (AID of $0.82 \mathrm{~mm}$ year ${ }^{-1}$ ) and height (AIH of $0.07 \mathrm{~m}$ ) are expected for saplings growing beneath the forest canopy (Mendes et al., 2013). The average height growth rate indicates that saplings used in the study (0.8-2.4 m tall) may take 300 years to reach the forest canopy (about $25 \mathrm{~m}$ ), and over a century to reach $100 \mathrm{~mm}$ in diameter at breast height. However, it should be noted that upper leaves of a tree receive more light as it grows, which could reduce the amount of time for a sapling to reach the forest canopy.

\section{Photosynthetic traits and nutrient use efficiency}

Values of photosynthetic rates and $g_{s}$ obtained in this study are similar to those found by others for Amazonian saplings acclimated to low light (Mendes \& Marenco, 2010; Azevedo \& Marenco, 2012; Marenco et al., 2014b). The positive effect of leaf $\mathrm{P}$ content on photosynthetic parameters is in agreement with data reported by Raaimakers et al. (1995). Low P concentration affects the whole metabolism of the plant cell inasmuch as $\mathrm{P}$ is a structural component of nucleic acids; it also has a major role in ATP generation (Marschner, 1995). The positive effect of leaf K, Ca and $\mathrm{Mg}$ content on photosynthetic parameters exemplifies the complexity of interactions between carbon gain and mineral nutrition of tropical rainforest, as suggested by Townsend et al. (2011). Mendes \& Marenco (2015) also found significant correlations between $\mathrm{K}, \mathrm{Ca}$ and $\mathrm{Mg}$ and photosynthetic parameters (electron transport and $\mathrm{CO}_{2}$ carboxylation rates). The reduction in either PNUE (as a function of leaf N) or PNUE with respect to leaf P content concurs with the results reported by Reich \& Schoettle (1988) and Mendes \& Marenco (2015). The positive correlation between photosynthesis and RGR is consistent with the results of Kruger \& Volin (2006) and supports the hypothesis that in the study area, both $A_{\text {pot }}$ and plant growth are responsive to variation in leaf $\mathrm{P}$ concentration. 


\section{Leaf nutrient content}

Leaf nutrient contents found in this study are similar to those reported by Mendes \& Marenco (2015). Except for leaf $\mathrm{P}$ concentration, the mean values of leaf nutrient content for $\mathrm{N}, \mathrm{K}, \mathrm{Ca}$ and $\mathrm{Mg}$ found in this study resemble those reported by Fyllas et al. (2009) for tropical trees. Fyllas et al. (2009) also found similar values for the N/K, K/Ca and the $\mathrm{K} / \mathrm{Mg}$ ratios. On the other hand, because of low leaf $\mathrm{P}$ concentrations, the N/P and K/P ratios reported in this study are almost twice the values reported by Fyllas et al. (2009) and Mendes \& Marenco (2015). There is a gap in the information regarding critical levels for most Amazonian tree species. For comparison, in Swietenia macrophylla and Brosimum alicastrum leaf nutrient content below 10-14 $\mathrm{mg} \mathrm{g}^{-1}$ (for $\mathrm{N}$ ) and 0.6
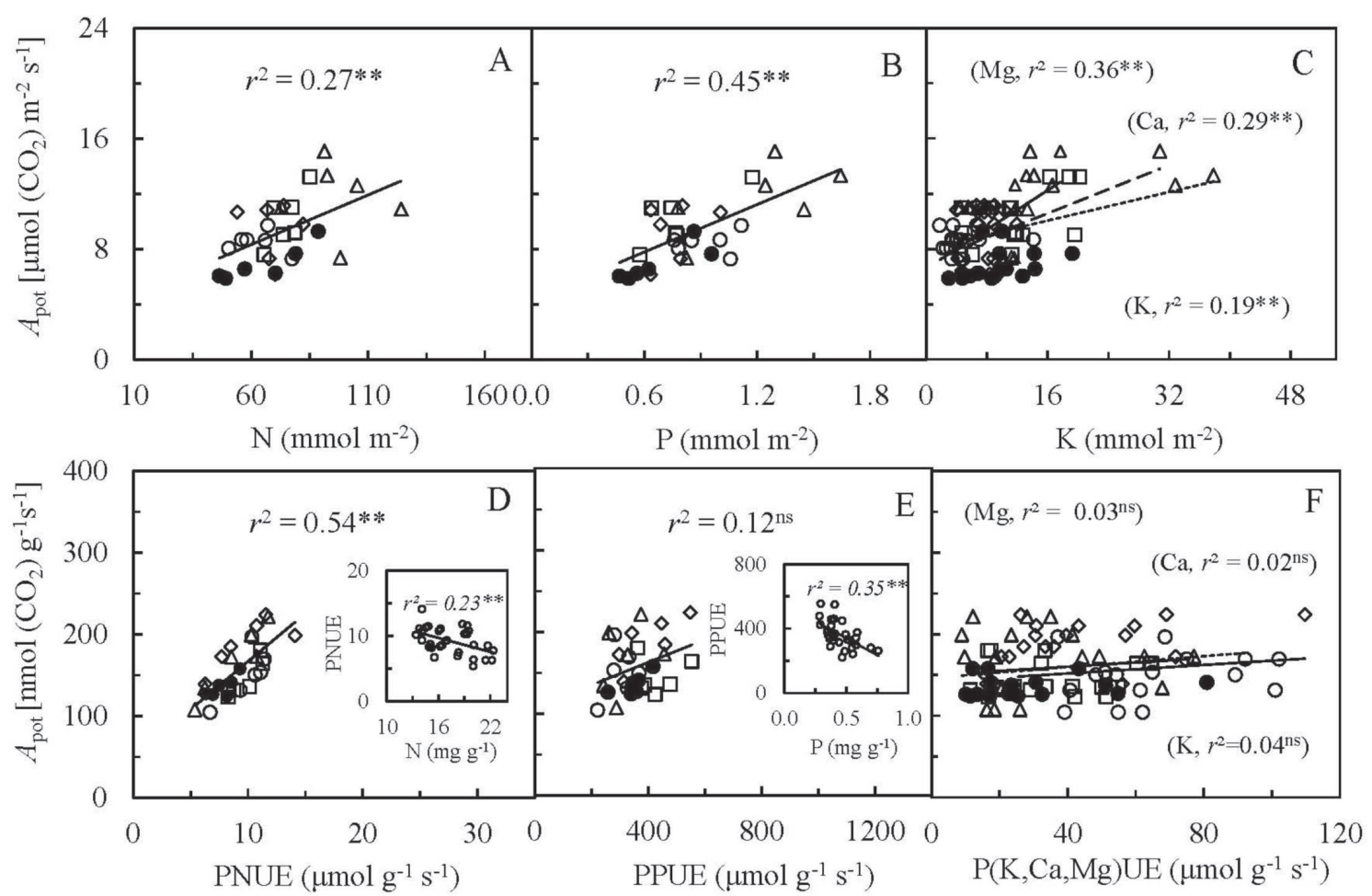

Figure 3. Potential photosynthesis $\left(A_{\text {pot }}\right.$ per unit area) as function of nitrogen $(\mathrm{N}, \mathrm{A})$, phosphorus $(\mathrm{P}, \mathrm{B})$, potassium $(\mathrm{K})$, calcium $(\mathrm{Ca})$ and magnesium $(\mathrm{Mg})(\mathrm{C})$. Relationship between potential photosynthesis ( $A_{\text {pot }}$ per unit mass) and nitrogen (PNUE, D), phosphorus (PPUE, E), potassium (PKUE), calcium (PCaUE) and magnesium (PMgUE) use efficiency (F) in Minquartia guianensis (circle, $\bigcirc)$, Guatteria olivacea (square, $\square$ ), Rinorea guianensis (diamond, $\diamond$ ), Simarouba amara (triangle, $\triangle$ ) and Duroia macrophylla (solid circle, $\bullet)$. Ns $=$ not significant $(p>0.05) ; * *$ highly significant $(p<0.01)$. Regressions in panel C and F: solid line is for Mg, dashed line for $\mathrm{Ca}$, and the dotted line is for $\mathrm{K}$. Inset in panel $\mathrm{D}$ and $\mathrm{E}$ show the relations between indicated variables across species. For further information, please see Table 2.

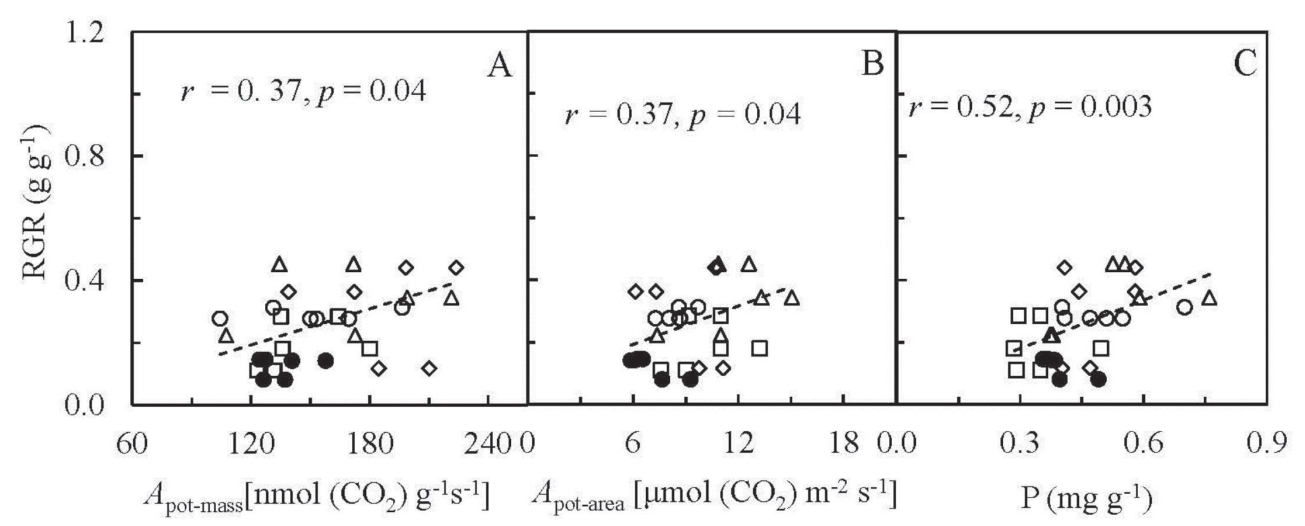

Figure 4. Pearson correlation between relative growth rate (RGR) and potential photosynthesis per unit mass $\left(A_{\text {pot msass }}, A\right), A_{\text {pot }}$ per unit area $\left(\mathrm{A}_{\mathrm{pot} \text { are }}, \mathrm{B}\right)$, and leaf phosphorus (P) content $(\mathrm{C})$ in Minquartia guianensis (circle, $\left.\mathrm{O}\right)$, Guatteria olivacea (square, $\square$ ), Rinorea guianensis (diamond, $\diamond$ ), Simarouba amara (triangle, $\triangle$ ) and Duroia macrophylla (solid circle, $\bullet$ ). For further information, please see Table 2. 
$\mathrm{mg} \mathrm{g}^{-1}$ (for $\mathrm{P}$ ) are under the sufficiency range (Drechsel \& Zech, 1991). In Quercus, leaf nutrient contents below 1.5, 3.0 and $10 \mathrm{mg} \mathrm{g}^{-1}$ for $\mathrm{Mg}, \mathrm{Ca}$ and K may limit growth (Marschner, 1995) and in Alnus acuminata, leaf nutrient content of 1.4, 2.4, and 7.6 $\mathrm{mg} \mathrm{g}^{-1}$ for $\mathrm{Mg}, \mathrm{Ca}$ and $\mathrm{K}$ are considered to be under the adequate range (Segura et al., 2005). If critical levels of Amazonian tree species are similar to those reported for other tree species, it seems plausible to conclude that $\mathrm{P}$ may be close to its critical level in leaf tissue in the study area.

The saplings had a rather high leaf $\mathrm{N}$ content, but a very low leaf $\mathrm{P}$ concentration $\left(0.45 \mathrm{mg} \mathrm{g}^{-1}\right)$, which leads to a high N/P ratio. Indeed, $\mathrm{P}$ values reported here are almost half those observed in canopy trees (Fyllas et al., 2009). It is remarkable that only $\mathrm{P}$ was positively correlated with sapling relative growth rates (Figure 4). The rather low $r^{2}$ value, nevertheless highly significant, $(0.52, p<0.01)$ is not unexpected as plant growth is the result of myriads of interactions between internal and external factors that ultimately end up in cellular growth. The high N/P ratio (Koerselman \& Meuleman, 1996) and the low leaf $\mathrm{P}$ content found in sapling leaves supports

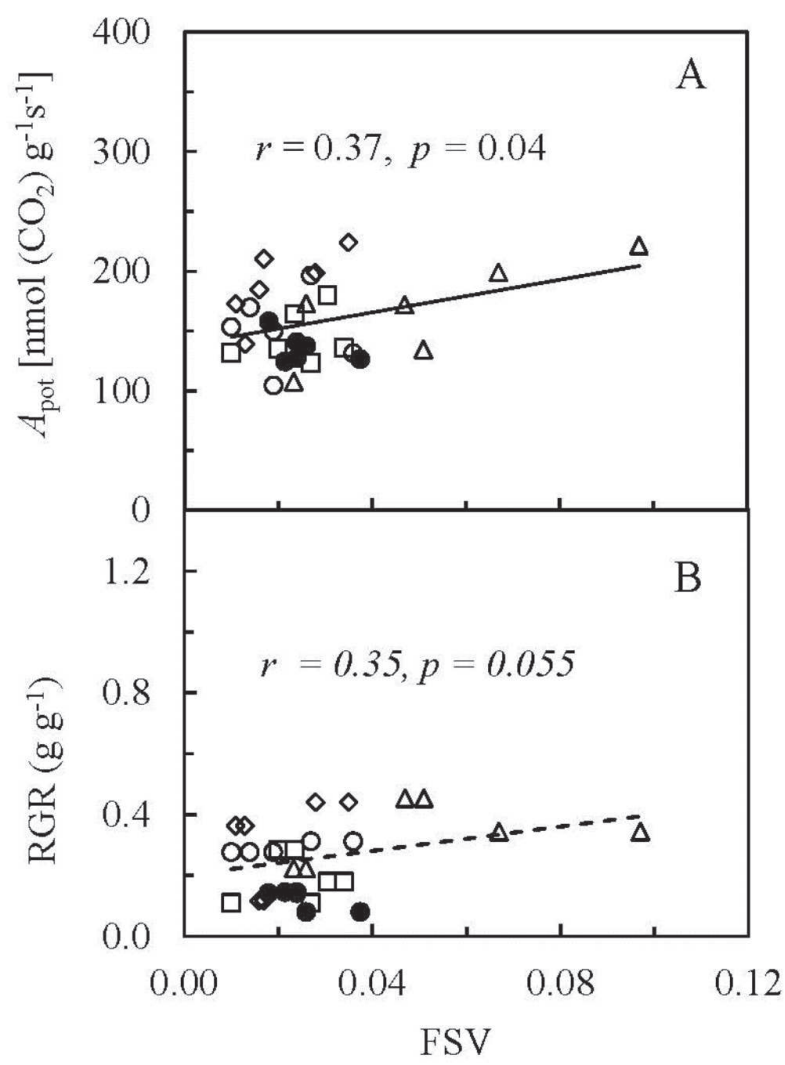

Figure 5. Pearson correlation between potential photosynthesis $\left(A_{\text {pot }}\right.$ per unit mass, $\left.\mathrm{A}\right)$ and relative growth rate (RGR, B) and the fraction of sky visible (FSV) in Minquartia guianensis (circle, O), Guatteria olivacea (square, $\square$ ), Rinorea guianensis (diamond, $\diamond$ ), Simarouba amara (triangle, $\triangle$ ) and Duroia macrophylla (solid circle, ๑). For further information, please see Table 2. the belief that in the old and highly weathered Amazonian soils, P can limit tree growth in this ecosystem (Reich \& Oleskyn, 2004). Nevertheless, Magalhães et al. (2014) failed to detect any significant plant response to the addition of $\mathrm{P}$, which suggests that the amount of $\mathrm{P}$ they added was not sufficient to cause any detectable effect on plant functioning; it is well known, for example, that oxisols have a high capacity for $\mathrm{P}$ fixation. Wright et al. (2011) reported that the addition of $\mathrm{P}$ only marginally enhanced seedling growth rates in a lowland tropical forest of Panama.

In this study, evidence for the positive association between sapling growth and leaf $\mathrm{P}$ content in central Amazonia is presented. If $\mathrm{P}$ is actually limiting tree growth in the deeply weathered Amazon soils, the enhanced effect of carbon dioxide deposition on the atmosphere will depend on the ability of the root system to increase P uptake efficiency. Enhanced mycorrhizal association can contribute to provide the surplus of $\mathrm{P}$ required to keep pace with the ongoing $\mathrm{CO}_{2}$ enrichment of the atmosphere (Lloyds \& Farquhar, 2008). It is known that most Amazonian trees are able to establish mycorrhizal association (Sturmer \& Siqueira, 2011), which enhances phosphorus uptake. Trees growing on low-phosphorus soils reduce foliar P concentration and increase its use efficiency (Hidaka \& Kitayama, 2011). Higher photosynthetic rates observed in brighter environments can provide the plant with the additional amount of carbon required to enhance mycorrhizal colonization and consequently to grow faster (Gerdemann 1968; Janos 1980)

\section{CONCLUSIONS}

Photosynthetic parameters of saplings did not respond to variations in soil water content between rainfall seasons, suggesting that the length of the dry season during the study period was not long enough to affect photosynthetic carbon gain of saplings in central Amazonia. Evidence for the positive correlation between leaf $\mathrm{P}$ content and growth of tree saplings in central Amazonia under natural conditions is presented. This finding suggests that the response of trees to increases in atmospheric $\mathrm{CO}_{2}$ concentrations may depend on the ability of trees to absorb additional amount of phosphorus to meet the mineral requirements to support long term growth.

\section{ACKNOWLEDGEMENTS}

The authors thank Fundação de Amparo à Pesquisa do Estado do Amazonas for financial support (Grant number FAPEAM-UA:062.03164/2012-6) and FAPEAM, CAPES and CNPq for scholarships. 


\section{REFERENCES}

Aerts R \& Chapin III FS (2000) The mineral nutrition of wild plants revisited: A re-evaluation of processes and patterns. Advances in Ecological Research, 30:01-67.

Azevedo GFC \& Marenco RA (2012) Growth and physiological changes in saplings of Minquartia guianensis and Swietenia macrophylla during acclimation to full sunlight. Photosynthetica, 50:86-94.

Clark DA \& Clark DB (2001) Getting to the canopy: Tree height growth in a neotropical rain forest. Ecology, 82:1460-1472.

Drechsel P \& Zech W (1991) Foliar nutrient levels of broad-leaved tropical trees: A tabular review. Plant and Soil, 131:29-46.

Elser JJ, Bracken MES, Cleland EE, Gruner DS, Harpole WS, Hilleb-rand H, Ngai JT, Seabloom EW, Shurin JB \& Smith JE (2007) Global analysis of nitrogen and phosphorus limitation of primary producers in freshwater, marine and terrestrial ecosystems. Ecology Letters, 10:1135-1142.

Ferreira SJF, Luizão FJ, Mello-Ivo W, Ross SM \& Biot Y (2002) Propriedades físicas do solo após extração seletiva de madeira na Amazônia Central. Acta Amazonica, 32:449-466

Fyllas NM, Patino S, Baker TR, Nardoto GB, Martinelli LA, Quesada CA, Paiva R, Schwarz M, Horna V, Mercado LM, Santos A, Arroyo L, Jimenez EM, Luizão FJ, Neill DA, Silva N, Prieto A, Rudas A, Silviera M, Vieira ICG, Lopez-Gonzalez G, Malhi Y, Phillips OL \& Lloyd J (2009) Basin-wide variations in foliar properties of Amazonian forest: phylogeny, soils and climate. Biogeosciences, 6:2677-2708.

Gerdemann JW (1968) Vesicular-arbuscular mycorrhiza and plant growth Annual Review of Phytopathology, 6:397-418.

Güsewell S (2004) N:P ratios in terrestrial plants: variation and functional significance. New Phytologist, 164:243-266

Hidaka A \& Kitayama K (2011) Allocation of foliar phosphorus fractions and leaf traits of tropical tree species in response to decreased soil phosphorus availability on Mount Kinabalu, Borneo. Journal of Ecology, 99:849-857

Hughes RF, Kauffman JB \& Jaramillo VJ (1999) Biomass, carbon, and nutrient dynamics of secondary forests in a humid tropical region of Mexico. Ecology, 80:1892-1907.

Janos DP (1980) Vesicular-arbuscular mycorrhizae affect lowland tropical rain forest plant growth. Ecology, 61:151-162.

Koerselman W \& Meuleman AFM (1996) The vegetation N:P ratio: A new tool to detect the nature of nutrient limitation. Journal of Applied Ecology, 33:1441-1450.

Kruger EL \& Volin JC (2006) Reexamining the empirical relation between plant growth and leaf photosynthesis. Functional Plant Biology, $33: 421-429$

Lloyd J \& Farquhar GD (2008) Effects of rising temperatures and $\left[\mathrm{CO}_{2}\right]$ on the physiology of tropical forest trees. Philosophical Transactions of the Royal Society of London, 363:1811-1817.

Lopes-Toledo L, Martinez M, Breuge MV \& Sterck FJ (2008) Soil and light effects on the sapling performance of the shade-tolerant species Brosimum alicastrum (Moraceae) in a Mexican tropical rain forest. Journal of Tropical Ecology, 24:629-637.

Magalhães NS, Marenco RA \& Camargo MAB (2014) Do soil fertilization and forest canopy foliage affect the growth and photosynthesis of Amazonian saplings? Scientia Agricola, 71:58-65.

Malhi Y \& Wright J (2004) Spatial patterns and recent trends in the climate of tropical rainforest regions. Philosophical Transactions of the Royal Society B-Biological Sciences, 359:311-329.

Marenco RA, Antezana-Vera SA, Gouvêa PRS, Camargo MAB, Oliveira MF \& Santos JKS (2014a) Fisiologia de espécies florestais da Amazônia: fotossíntese, respiração e relações hídricas. Revista Ceres, 61:786-799.
Marenco RA, Nascimento HCS \& Magalhães NS (2014b) Stomatal conductance in Amazonian tree saplings in response to variations in the physical environment. Photosynthetica, 52:493-500

Marenco RA \& Vieira G (2005) Specific leaf area and photosynthetic parameters of tree species in the forest understorey as a function of the microsite light environment in central Amazonia. Journal of Tropical Forest Science, 17:265-278.

Marschner H (1995) Mineral nutrition of higher plants. $2^{\text {nd }}$ edition. London, Academic Press. 889p.

Mendes KR \& Marenco RA (2010) Leaf traits and gas exchange in saplings of native tree species in the Central Amazon. Scientia Agricola, 67:624-632.

Mendes KR \& Marenco RA (2015) Photosynthetic traits of tree species in response to leaf nutrient content in the central Amazon. Theoretical and Experimental Plant Physiology, 27:51-59.

Mendes KR, Marenco RA \& Magalhães NS (2013) Crescimento e eficiência fotossintética de uso do nitrogênio e fósforo em espécies florestais da Amazônia na fase juvenil. Revista Árvore, 37:707-716.

Oliveira AA \& Scott AM (1999) A central Amazonian terra firme forest. I. High tree species richness on poor soils. Biodiversity and Conservation, 8:1219-1244.

Pearcy RW (1990) Sunflecks and photosynthesis in plant canopies. Annual Review of Plant Physiology and Plant Molecular Biology, 41:421-453

Raaimakers D, Boot RGA, Dijkstra R, Pot S \& Pons T (1995) Photosynthetic rates in relation to leaf phosphorus content in pioneer versus climax tropical rainforest trees. Oecologia, 102:120-125.

Reich PB \& Oleskyn J (2004) Global patterns of plant leaf N and P in relation to temperature and latitude. Proceedings of the National Academy of Sciences of the United States of America, 101:1100111006.

Reich PB \& Schoettle AW (1988) Role of phosphorus and nitrogen in photosynthetic and whole plant carbon gain and nutrient use efficiency in Eastern white Pine. Oecologia, 77:25-33.

Santiago LS, Wright SJ, Harms KE, Yavitt JB, Korine C, Garcia MN \& Turner BL (2012) Tropical tree seedling growth responses to nitrogen, phosphorus and potassium addition. Journal of Ecology, 100:309316.

Segura M, Castillo A, Alvarado A \& Blanco F (2005) Variación del contenido foliar de nutrimentos de Alnus acuminata. Agronomía Costarricense, 30:53-63.

Sturmer SL \& Siqueira JO (2011) Species richness and spore abundance of arbuscular mycorrhizal fungi across distinct land uses in Western Brazilian Amazon. Mycorrhiza, 21:255-267.

Townsend AR, Cleveland CC, Houlton BZ, Alden CB \& White JWC (2011) Multi-element regulation of the tropical forest carbon cycle. Frontiers in Ecology and the Environment, 9:09-17.

Wagner F, Rossi V, Stahl C, Bonal D \& Herault B (2012) Water availability is the main climate driver of neotropical tree growth. Plos One, 7. DOI: 10.1371/journal.pone.0034074

Wright SJ, Yavitt JB, Wurzburger N, Turner BL, Tanner EVJ, Sayer EJ, Santiago LS, Kaspari M, Hedin LO, Harms KE, Garcia MN \& Corre MD (2011) Potassium, phosphorus, or nitrogen limit root allocation, tree growth, or litter production in a lowland tropical forest. Ecology, 92:1616-1625. 